\title{
The Arrangement of Rights and Obligations in The Implementation of Akad Syirkah Mudharabah Ayam Geprek Sa'i in Yogyakarta
}

\author{
Indah Maulida Sekar Ayu ${ }^{1^{*}}$, Dewi Nurul Musjtari \\ ${ }^{1,2}$ Program Studi Hukum, Fakultas Hukum, Universitas Muhammadiyah Yogyakarta, Indonesia \\ *Corresponent Author: indah.maulida.2016@law.umy.ac.id
}

Info of Article
Submitted: 03-09-2020
Reviewed: $28-09-2020$
Revised: $30-10-2020$
Accepted: $20-11-2020$
DOI: $10.18196 / m l s . v 2 i 1.11485$ arrangement of rights and obligations in the implementation of Akad Syirkah Mudharabah arrangement of rights and obligations in the implementation of Akad Syirkah Mudharabah Ayam Geprek Sa'i in Yogyakarta. This research was conducted using empirical normative research methods that are based on the regulation of Akad Syirkah Mudharabah Ayam Geprek Sa'i then compare it by looking at the facts that occur and looking at the prevailing laws and regulations in Indonesia and arranged using qualitative methods, with using systematically arranged and descriptive explanation. The results of this research is the arrangement of rights and obligations stipulated in Article 6 of the Akad Syirkah Mudharabah Ayam Geprek Sa'i in Yogyakarta, but have not yet proceeded in accordance with the existing regulations that has been agreed in the agreement.

Keyword: akad syirkah mudharabah, ayam geprek sa'i, rights and obligations.

\section{Introduction}

The development of the business world that produces new forms of business, including franchise business systems, business systems with partnership agreements, profit-share business systems with business cooperation agreements, and others. In business development, the profit-share system that uses business cooperation agreements is one of the strategies that can be chosen by businesses. the cooperation agreement is a formal business document outlining the basic terms of agreement between two or more persons in carrying out a joint venture with one mutually beneficial purpose; the legal basis of the agreement is Article 1313 Civil Code which is a covenant of a deed of one person or more binding himself to one person or more'.

In the business sector that uses a profit-share system based on business cooperation agreements in Indonesia many found in the field of food, for example Ayam Geprek Sa'i in Yogyakarta. Ayam Geprek Sa'i is managed through Sharia-based partnership that is engaged in a fast-food restaurant, it offers some forms of partnership 
management to other parties such as franchise free, revenue share of $30 \%$ management, and $70 \%$ of partnership profit. ${ }^{1}$

This agreement on Ayam Geprek Sa'i is a sharia-based agreement, it is in the agreement itself that explains the use of Akad Syirkah Mudharabah, where in its implementation uses the principle of revenue sharing which is the profit sharing of the proceeds from a business between the owner of the fund (shahibul maal) and the fund manager (mudharib), in the agreement here is referred to as the owner of the capital and the owner of the brand.

Basically Akad Syirkah Mudharabah Ayam Geprek Sa'i is a standard/standard agreement in which there is a standard clause, which is the owner of the brand full authority over the determination of the contents of the Akad Syirkah Mudharabah itself, which includes the rights and obligations of the parties. Then, business people who are interested in becoming the owner of Ayam Geprek Sa'i capital only have the right to agree to all the contents of the agreement or are deemed to have never done at all if they do not agree to the contents of the agreement, which means that the owner of the capital is not given the opportunity to change part or all of the contents of the Akad Syirkah Mudharabah Ayam Geprek Sa'i. The use of agreements of this type of standard agreement, there is usually the content of the agreement that more protects the interests unilaterally, especially in terms of the division of the rights and obligations of each relevant party.

Within the cooperation agreement, there is a legal relationship that raises the consequences of the law that makes the linkage between the two, where each bound party has the rights and obligations to be followed during the agreement, which is also valid as a law for its creators in accordance with Article 1338 Paragraph (1) of Civil Code. However, the execution of the agreement does not always run in accordance with the expectation since a problem raises among the parties due to the loss that can occur on the party of the one resulting from the negligence of an other party. The negligence on either the parties who are delayed or do not perform obligations that have been paid by both parties harms an other party.

Thus, there is a need to review the Akad Syirkah Mudharabah on the brand Ayam Geprek Sa'i with the attention of das solen das sein which means seeing from the agreement made then compare it to the facts happening in the field and compare it to the relevant regulations that apply today, The aim is to find the right and obligation arrangement of the related parties, especially for the capital owner in the agreement so that it is expected to provide legal protection to the capital owner itself and can prevent the existence of arbitrariness by one party that could harm another party; then this can also be an evaluation material for business actors.

\footnotetext{
1 Ayamgeprek-sai.com, Ayam Geprek Sa'i adalah manajemen kemitraan berbasis syariah, 2017, < http://ayamgeprek-sai.com/tentang_kami.html > [accessed on 30 November 2019 14:00 WIB]
} 
Based on the above description, the author is interested in researching how the arrangement of rights and obligations in the implementation of Akad Syirkah Mudharabah Ayam Geprek Sa'i in Yogyakarta?

\section{Method}

The type of legal research conducted in this research uses the type of normative empirical, which is legal research by means of a fact approach with the way to conduct observations and research in the field. Then the observation and research results are examined based on the relevant legislation as a reference for solving problems and giving solutions. This research uses primary and secondary data types, namely; Primary data is the data obtained from the research done directly in the community, namely conducting interviews by asking a question orally or writing on the capital owner and owner of the brand Ayam Geprek Sa'i in Yogyakarta. Secondary data is data obtained from library studies, i.e. books, laws, journals, and files or archives relating to research.

The research is conducted at several places in Yogyakarta, including; Central Office / Restaurant of Ayam Geprek Sa'i, Jalan Sorogenen No. 11 B, Nitikan, Sorosutan, Umbulharjo, Yogyakarta and Restaurant Branch of Ayam Geprek Sa'i Sambilegi, Jalan Waringi, Sambilegi Baru, Nanggulan, Maguwoharjo, Kecamatan Depok, Kabupaten Sleman, Daerah Istimewa Yogyakarta. The sources of this research is a person who gives an opinion on the research object, to represent a personal or related institution in order to provide clear information about the data that the researcher needs. The speaker in this study was Mr. Mardoto who represented the brand owner Ayam Geprek Sa'i and Mr. Hafidz as the capital owner of Ayam Geprek Sa'i. The author performs analysis on the results of the research by using qualitative methods, where the data obtained compiled first and then processed systematically and linked with the theory and provisions of legislation in the field of civil law, especially in the business cooperation agreement. The results of the research are displayed in a descriptive form, which describes or describes the actual condition in the field, so that the understanding of the existing problems can be obtained.

\section{Analysis and Results}

Akad and Agreement are a unit, where Akad is an alliance derived from the Arabic word with the basis of Islamic law, while the Agreement is an alliance derived from the Indonesian word with the basis of civil law. The two legal sources can be used together on a single alliance.

An agreement of at least two parties give agreement to each other, so there is an interaction between the two. ${ }^{2}$ It refers to any agreement that has been agreed to result in

\footnotetext{
${ }^{2}$ Hananto Prasetyo, (2017), Perjanjian Sportentertainment Berbasis Nilai Keadilan (Studi Kasus pada Petinju Profesional di Indonesia), Jurnal Pembaharuan Hukum, Vol. 4 No. 1 Edisi Januari-April, p. 68.
} 
a legal relationship which then arises the right and obligation for each Party to be bound by the agreement. The legal relationship itself is a relationship between a legal subject that is one with another legal subject that poses a legal consequence of rights and obligations. ${ }^{3}$ The subject of the law consists of two kinds, namely human beings and legal entities. In the agreement, the two subjects of the law are positioned as aqidain. But must have the proficiency (ahliyah) and authority (wilayah) to act before the law in order to make a covenant. In the implementation of Akad Syirkah Mudharabah Ayam Geprek Sa'i, it involves two legal subjects, namely Brand Owner and Capital Owner.

Ayam Geprek Sa'i is a fast food restaurant established in 2017 in Yogyakarta by 4 people, including Mardoto, Erwan Barudi, Wagiyanto, and Heru. These four people became founders as well as owner of Ayam Geprek Sa'i Brand. While the partner or capital owner can consist of a community of businesses who bind themselves with the brand owner to conduct business in the culinary field in the ready-made restaurant Ayam Geprek Sa'i. ${ }^{4}$

Ayam Geprek Sa'i is fast restaurant that uses the management of sharia-based partnerships in the food industry, with excellent products of Ayam Geprek, Ayam Goreng Tepung, Ayam Penyet, Steak dan Nasi Goreng, through the concept of serving healthy food, quality, halal with a distinctive flavour. In promoting the Ayam Geprek Sa'i products, they use social media, banners, brochures, free vouchers of products, etc. Whereas, in promoting the partnership of Ayam Geprek Sa'i, they use social media, offering directly to customers and others interested in the partnership of Ayam Geprek Sa'i. ${ }^{5}$

The form of partnership management offered by Ayam Geprek Sa'i among others are; Franchise free or in other words the share of the $30 \%$ results that can be obtained for management and $70 \%$ that can be obtained for the partners of profit. It is based on the interest of the brand owner in the concept that shar'i or in other words do not violate the rules of religion. The Ayam Geprek Sa'i has several branches in some areas in Java and outside Java. ${ }^{6}$

In the procedure of investment sharing of Ayam Geprek Sa'i, in its business activities, the managment uses the principle of the outcome. Revenue share is the profit distribution of the result of a business between the fund owner (Shahibul Maal) with the fund manager (Mudharib), in the agreement of Ayam Geprek Sa'i is called as capital

\footnotetext{
${ }^{3}$ Inda Rahadiyan dan M. Alif Akbar Pranagara, (2017), Bentuk Hubungan Hukum Para Pihak dan Tanggung Jawab Agen dalam Penyelenggaraan Branchless Banking di Indonesia, Jurnal Hukum IUS QUIA IUSTUM No. 2 Vol. 24. Edisi April.

4 Result of interview with Mr. Mardoto, Brand Owner and Management of Ayam Geprek Sa'i, in Yogyakarta, on March 12th 2020, at 04.00 pm.

5 Result of interview with Mr. Mardoto, Brand Owner and Management of Ayam Geprek Sa'i, in Yogyakarta, on March 12th 2020, at 04.00 pm.

${ }^{6}$ Result of interview with Mr. Mardoto, Brand Owner and Management of Ayam Geprek Sa'i, in Yogyakarta, on May 11th 2020, at 06.28 am.
} 
owner and brand owner. In the agreement of Ayam Geprek Sa'i also mentioned, this is what makes them use Akad Syirkah Mudharabah.

Akad and Agreement are a unit, where Akad is an alliance derived from the Arabic word with the basis of Islamic law, while the Agreement is an alliance derived from the Indonesian word with the basis of civil law. The two legal sources can be used together on a single alliance. Akad is defined as an alliance between ijab and qabul in a way that is justified by syara' which establishes the legal consequences of its object. Ijab is a first-party statement regarding the content of the desired alliance, while qabul is the second party statement to accept it. Ijab and qabul were held with the intention of showing the voluntary reciprocity of the alliance carried out by the two parties concerned.

While in the Compilation of Sharia Economic Law (KHES) Article 136 on Syirkah defines that Syirkah is a cooperation conducted between two or more capital owners to do joint ventures with an disproportionate amount of capital, each party participates in the company, and the profit or loss is divided equally or on the basis of the proportion of capital. Syirkah is divided into two: Syirkah Musyarakah and Syirkah Mudharabah.

And the understanding of Mudharabah that is the wording is due to amil and mudharib putting mudharabah to work by trade (tijarah) and seeking profit with demand from the owner of the capital ( $\mathrm{rab}$ al-mal). In the term, mudharabah means capital owner submitting capital to an amil to trade with the capital, where the profit is divided between the two by a portion of the share as required in the agreement. ${ }^{7}$

Akad Syirkah Mudharabah itself is an agreement between two parties, the first party as the owner of capital and the other party as a capital executor or a person who is skilled in trading to operationalize such capital in the productive efforts and profit from the business is divided two in accordance with the agreement. And if there is a loss, then the losses are borne by the capital, while for the executor of the loss of capital is lost time, mind and bad will have been poured out. ${ }^{8}$

Basically the law of Akad Syirkah Mudharabah is mubah or can. The following is the evidence of the Qur'an and hadith that explains the Akad Syirkah Mudharabah among others;

In the Qur'an has been explained:

"O you who believe! And let a writer among you write it down correctly. And let not the writer refuse to write it as Allah has taught him, and let him write, and let him who is in debt write it down, and let him fear Allah his Lord, and let him not reduce anything of his debt. If the debted one is weak or weak, or he is incapable of

\footnotetext{
${ }^{7}$ Chefi Abdul Latif, (2020), Pembiayaan Mudharabah Dan Pembiayaan Musyarakah Di Perbankan Syariah, Jurnal Ilmu Akuntansi dan Bisnis Syariah, Vol. 2, No. 01, p. 11.

8 Mahmudatus Sa'diyah, Meuthiya Athifa Arifin, (2013), Mudharabah dalam Fiqih dan Perbankan Syari'ah, EQUILIBRIUM No. 2 Vol. 1. Edisi Desember, p. 306.
} 
disingencing, then let his guardian sow honesty. And bear witness with two witnesses from among you. If there are no two oang men, then a man and two women from the witnesses you are pleased with, that if one forgets, then one reminds him. Let not the witnesses be reluctant when they are called. And do not be weary of writing down the debt, small or large until the time of paying it. That is more just with Allah, and more strengthened in testimony, and closer to your doubts. If you do not write it down, there is no sin on you if you do not write it down. And bear witness when you trade; and let not writers and witnesses trouble each other. If you do so, it is indeed an insane to you. And fear Allah; God teaches you; And Allah is All-Knowing, All-Wise. Asbabun Nuzul : When the Prophet $(s)$ came to the mosque the first time the indigenous people used to rent out their garden within one, two, or three years." (Q.S. Al-Baqarah: 282)

"Indeed, most of them do wrong against others, except those who believe and do good deeds." (QS Shad 38:24)

“...It is no sin for you to seek grace from your Lord.” (QS. Al-Baqarah Ayat 198)

Imam Al-Bukhari narrated that Abu Manhal once said:

"Me and my syirkah once bought something in cash and debt. Then we were approached by Barra' ibn Azib. We then asked him. He said, "Zayd ibn Arqam also practiced this. Then we asked the Prophet about our actions. He said, "The goods that are obtained in cash, please take it, while it is acquired in debt please return it." (HR al-Bukhari)

"It was told to us Hasan ibn Ali al-Khallal, told to us Bisri ibn Tsabit al-Bazzar, told us Nashr ibn al-Qasim of 'Abd al-Ba'allaah ibn David, from Shalih ibn Shuhaib r.a. that the Messenger of Allaah (peace and blessings be upon him), and mixed wheat with flour for the purposes of the house, not for sale." (HR Ibnu Majah No. 2280, Kitab AtTijarah)

It was narrated that some companions gave away the property of the orphans as mudharabah, and no one denied them. Therefore, it is seen as ijma ${ }^{\text {ee } 9}$

It is permissable for a Muslim to do so between a fellow unbeliever or between a Muslim and a disbelief. Therefore, a Muslim can also do charity with people of different religions such as Christians, Majusi and other infidels while anything that is done is an effort that is not forbidden to Muslims. ${ }^{10}$

As a fund manager, the brand owner will play the funds in the form of business Management Services Ayam Geprek Sa'i, which then profits from the business activities, will be divided into the owner of the capital as the owner of the fund. Among the factors that affect the amount of acquisition for such result are the agreement between the capital owner and the brand owner, prediction of profit to be obtained, market response, ability to market the goods and the validity period of the contract. ${ }^{11}$

In conducting business activities for the outcome of the brand Ayam Geprek Sa'i, the owner of the capital must be legally authorized by the brand owner through the Akad

\footnotetext{
${ }^{9}$ Chefi Abdul Latif, Loc.Cit.

${ }^{10}$ Ibid., p. 4.

${ }^{11}$ Muhammad Syafi'i Anotnio, (2001), Bank Syariah: Dari Teori ke Praktik, Jakarta: Gema Insani, p. 97.
} 
Syirkah Mudharabah made in the form of a raw agreement. According to the Akad Syirkah Mudharabah Ayam Geprek Sa'i, regarding the distribution of rights and obligations between the parties and brand owners, both parties had agreed to use centralized management system. In other words, the owner of the brand determines that the owner of the capital is only entitled to accept and approve the contents of the agreement containing the parties' rights and obligations. If the owner of the capital does not accept and approve it, then the agreement is deemed void or never occurred at all. In other words the agreement contains the rights and obligations of the parties that cannot be changed by the capital owner. It means if there is a business person interested to open a business brand Ayam Geprek Sa'i by becoming a capital owner, then the business must agree with the brand owner through a business cooperation agreement. However, if the business does not agree with the contents of its agreements, then the agreement is not directly cancelled or deemed not to do so.

Here is the pillars of Akad Syirkah Mudharabah according to jumhur ulama;

a. Parties that do the contract, namely the owner of the fund (Shahibul Maal) and the capital manager (Mudharib)

b. Capital (Ra'sul Maal)

c. Businesses carried out (Al-'Amal)

d. Profit (Ribh)

e. Statement of ijab and qabul (Sighat Akad)

While the terms of the Akad Syirkah Mudharabah relate to the pillars, as follows;

1. The parties who do the Akad Syirkah Mudharabah are required to have the ability to be burdened with law/legal proficiency (mukallaf) to do the deal, in this case the owner of the capital (shahibul maal) will give the power and the capital manager (mudharib) to receive the power, because in the Akad Syirkah Mudharabah contained a contract of wakalah/Kuasa.

2. The capital (Ra'sul Maal) in the Akad Syirkah Mudharabah must meet the following requirements; Capital must be in the form of exchange tools (money), Capital must be known so that it is easy to measure, Capital must be in cash, Capital must be transferred /handed over from the owner of capital (shahibul maal) to the capital manager (mudharib). ${ }^{12}$

The elements of Akad there are:

1. Shighat al-aqad (statement to bind yourself)

Is the way in which the self-binding statement is carried out, meaning in the case of the making of a contract then the parties must convey orally/in writing the terms and

${ }^{12}$ Chefi Abdul Latif, Op.Cit., p. 13. 
conditions of the agreement as it may cause legal consequences, because the intent that has not been conveyed to the other party has no legal consequences at all.

\section{Al-Ma'qud alaih/Mahal Al' aqad (object of akad)}

The object of the agreement depends heavily on the agreement made. In the agreement of selling and selling objects bias in the form of goods or services, in the leases of objects are the benefits of the goods rented and rented money. In connection with the object of this agreement must meet the requirements in the form of having existed at the time the contract was held, justified by the syara', can be determined and known, and may be submitted at the time of the agreement.

\section{Al-Muta'aqidain/Al'-Aqidain (parties who do the contract)}

The parties who do the contract must both have the ability to take legal action in the sense that it is mature and common sense. If an agreement is made by a person who does not have proficiency, such as involving children, then he must be represented by his guardian. And to be a guardian must meet the requirements in terms of the ability to carry out the task perfectly, the equality of views (religion) between the guardian and the one he represents, fair, trustees, and able to safeguard the interests of the person who is in his guardianship.

\section{Maudhu' al'aqd (the aims of Akad)}

According to the fuqaha, the purpose of a contract must be in line with the will of the syara', so that if the purpose is contrary to the syara' then it results in the validity of the covenant made. The goal must be there at the time of the event, it can last until the end of the contract, and must be justified by the syara'.

As in the law of the Agreement according to the Civil Law which recognizes the principles of freedom of contract, the principle of personality, and the principle of good faith, in the context of islamic law also know the principles of the law of the Akad. The principles of Akad are as follows:

\section{Al-Hurriyah (The Principle of Freedom)}

This principle is a basic principle in Islamic covenant law, in the sense that the parties are free to make a covenant or a contract. This principle of freedom of contract should be no element of coercion, error, and deception.

\section{Al-Musawah (The Principle of Equality)}

This principle contains the understanding that the parties have the same position in determining the terms and conditions of a contract.

\section{Al-'Adalah (The Principle of Justice)}

The implementation of this principle in a contract requires the parties to do the right thing in the disclosure of will and circumstances, fulfilling all its obligations.

4. Al-Ridha (The Principle of Willingness) 
This principle states that any transaction struck must be on the basis of willingness between each party, shall be based on a free agreement from the parties.

5. Ash-Shidq (The Principle of Truth)

That in Islam everyone is forbidden to commit lies and fraud, because the form of fraud / lies is very influential in the validity of the agreement. The agreement, which contains an element of lies/fraud, gives the other party the right to stop the implementation of the contract.

\section{Al-Kitabah (The Principle of Written)}

That any agreement should be made in writing, is more relevant in the interests of proof in the event of a dispute in the future. ${ }^{13}$

The subject of the law consists of two kinds, namely human beings and legal entities. In the agreement, the two subjects of the law are positioned as aqidain. But must have the proficiency (ahliyah) and authority (wilayah) to act before the law in order to make a covenant. Among the subjects of the law are;

1. Human

The actions of a person are said to have the ability to be the subject of the law when it meets two criteria, namely:

a. Have proficiency (ahliyah). Proficiency in receiving law (ahliyah al-wujub) and proficiency to act law (ahliyah al-ada).

b. Have the authority (wilayah) to perform legal actions. The meaning of authority is the power to exercise the right to do tasharruf. The authority to carry out tasharruf can be created in addition to the cause of ownership (milkiyah), also because of the representative (wakalah) to carry out the mandate.

\section{Legal Entities}

The legal entity is said to be the subject of the law because it consists of a group of people who commit legal acts (tasharruf). Legal entities are the result of analogies of human existence as the subject of law.

Then, regarding the object of the law or in Arabic is referred to as Mahal al-'aqd. The meaning of a legal object or an object is something that is used by syara' as an object and imposed on it as a result of the law inflicted. The object of the agreement is divided into two, namely the property and the benefits of the deeds themselves. According to the fuqaha, in order for something to be used as an object of contract must meet the following requirements;

\footnotetext{
${ }^{13}$ Ahmad Azhar Basyir, 2000, Op.Cit., p 78.
} 
a. Something that becomes the object of the agreement must be in accordance with sharia principles (masyru').

b. The clarity of the agreement object so that it can be handovered. This is to avoid fraud.

c. The condition of perfect ownership of the object of the agreement. Islam basically prohibits transactions against objects that are not authorized. Holding something without the owner's knowledge is named after the fudhuli agreement.

A business person who wants to become a capital owner, needs the conditions that he/she must;

1. Be subject to applicable law in Indonesia

2. Own a business space that has economic potential (both property rights and rent) with an area of approximately $100 \mathrm{~m} 2$

3. Own capital without debt/RIBA

4. Understand and approve the business concept of Ayam Geprek Sa'i

By looking at the above conditions, of course, to make a treaty must comply with the basic provisions stipulated in Article 1320 of the civil law, that a treaty must mutually agree to bind itself, with age deemed to have been proficient, then by reason of a certain thing that would be an object in the agreement clearly, and of course with a lawful reason where the agreement is not contrary In that case, the creation of Akad Syirkah Mudharabah Ayam Geprek Sa'i has been in accordance with the provisions of Article 1320 of Civil Code.

In this study, the two parties are Hafidz, owner of Ayam Geprek Sa'i branch of Maguwoharjo as capital owner and Mardoto, one of the brand owners of Ayam Geprek Sa'i.

Akad Syirkah Mudharabah Ayam Geprek Sa'i is a treaty that binds the parties who agreed to run the culinary business of Ayam Geprek Sa'i created by the brand owner with the business who interested to become the owner of the capital in the business of Ayam Geprek Sa'i. In this case, the brand owner and the capital owner are the subject of the law that is committed to doing business by developing and managing culinary business in order to benefit both parties.

The Akad Syirkah Mudharabah Ayam Geprek Sa'i written and signed by both parties should be a legal certainty that can protect the parties relating to the cooperation agreement that aims to prevent the existence of arbitrariness in order to maintain the stability of peaceful business relations and security assured. However, on the Akad Syirkah Mudharabah Ayam Geprek Sa'i itself there are some points that make the agreement itself weak. 
The first weakness of the Akad Syirkah Mudharabah Ayam Geprek Sa'i, diantaranya is the arrangement of the contents of the Akad Syirkah Mudharabah which is still not in accordance with the standards of anatomical agreement as seen from part of recitals or the background of the situation in a treaty. The recitals usually explain the reasons of the alliance.In the recietals, the list of the causes are mentioned because these are the conditions of the validity of an agreement. ${ }^{14}$

Another weakness is found in Article 6 Akad Syirkah Mudharabah Ayam Geprek Sa'i which explains the rights and obligations of the parties involved in the agreement. It still has a deficiency, especially on the rights and obligations of the owner of the capital, between the amount of the contents of the rights unbalanced by the amount of the contents of the obligation; it should be the sum of each rights and balanced obligation. Then, regarding the explanation of the profit sharing is not mentioned in the article rights and obligations, such as explanations about the time of the profit sharing and the division through direct payment or transfer, in the article is not explained in detail.

The less detailed explanation in the contents of the Akad Syirkah Mudharabah Ayam Geprek Sa'i can be the reason for weak legal force that makes legal protection for the parties to be weak, especially for the owner of the capital. Since the Akad Syirkah Mudharabah Ayam Geprek Sa'i was made by using the standard clause, in which the agreement is made unilaterally by the owner of the brand, and the party of capital owners can only approve it or if it does not agree on the contents of its agreement, then it is deemed not to commit at all. Thus, the capital owner does not have the opportunity to change the contents of the agreement either half or completely.As the results, the change or revision of the contents of the Akad Syirkah Mudharabah Ayam Geprek Sa'i is required in order to create a treaty that further guarantees its legal protection for the parties attached.

Some of the things mentioned above that make legal protection for the parties weak, especially for the owners of capital. Therefore, a change or revision of the contents of the Akad Syirkah Mudharabah Ayam Geprek Sa'i is necessary in order to create an agreement that further guarantees its legal protection for the bound parties.

Regarding the contents of Akad Syirkah Mudharabah Ayam Geprek Sa'i has been complies with the Pacta Sunt Servanda, where the content of the agreement binds the parties who have agreed to make the agreement so as to give birth to a right and obligation for the parties, the agreement is also made legally so as to have full legal power. Pursuant to Article 1314 of the Civil Code, the Akad Syirkah Mudharabah Ayam Geprek Sa'i includes an incriminated agreement, in which the parties bound to give something, do something or not do something. In doing so, the Akad Syirkah Mudharabah Ayam Geprek Sa'i must clearly contain the rights and obligations between

\footnotetext{
${ }^{14}$ Hasanuddin Rahman, (2003), Aspek-Aspek Hukum Pemberian Kredit Perbankan di Indonesia, Bandung: Citra Aditya Bakti p. 96.
} 
the brand owner and the capital owner. The rights and obligations of the Parties shall be governed by the Akad Syirkah Mudharabah Ayam Geprek Sa'i, including;

1. Rights and Obligations of the Capital Owners Ayam Geprek Sa'i

a. Rights of Capital Owners

The rights of the capital owner are something that the capital owner will receive as the first party in an Akad Syirkah Mudharabah Ayam Geprek Sa'i. Pursuant to Article 6 Paragraph (1) of the Akad Syirkah Mudharabah Ayam Geprek Sa'i on the rights and obligations of the capital owner, including:

1) Entitled to use the Brand of business with an agreed address in the establishment

2) Entitled to monitor or supervision of the business that is being run by the Brand owner as a second party as long as it does not contradict the business policy set by the second party

3) Reserves the right to control or review the business activities

4) The right to submit proposals and suggestions to the second party to repair and/or improve the business activities in progress

b. Obligations of Capital Owners

The obligation of the capital owner is something to be done by the capital owner as the first party in an Akad Syirkah Mudharabah Ayam Geprek Sa'i, pursuant to Article 6 Paragraph (1) of Akad Syirkah Mudharabah Ayam Geprek Sa'i regarding the rights and obligations of the capital owner, including:

1) Have to make the purchase of raw materials, spices, wrappers and marketing tools according to the needs of the outlet only to the second party or other party appointed second party.

2. Rights and Obligations of the Brand Owner of Ayam Geprek Sa'i

a. Rights of Brand Owner

The Brand owner's right is something that the Brand owner will receive as a second party in a Akad Syirkah Mudharabah Ayam Geprek Sa'i. Pursuant to Article 6 Paragraph (2) of the Akad Syirkah Mudharabah Ayam Geprek Sa'i regarding the rights and obligations of the owner of the Brand, including:

1) The right to use business capital in business activities that have been agreed by both parties

2) The right to manage and determine the policies in the business activities

a. Obligations of Brand Owner 
Brand owner's obligation is something that the Brand owner must do as a second party in an Akad Syirkah Mudharabah Ayam Geprek Sa'i. Pursuant to Article 6 Paragraph (2) of the Akad Syirkah Mudharabah Ayam Geprek Sa'i regarding the rights and obligations of the owner of the Brand, including:

1) Have to manage the business capital that has been received from the first party for an agreed business activity

2) Required to report the business results in detail and written to the first party

3) Have to manage business activities seriously and in a planned

The rights and obligations of the parties in the Akad Syirkah Mudharabah Ayam Geprek Sa'i, has been in accordance with Article 1338 of the Civil Code 'all agreements made in accordance with the law prevails as a statute for those who make it. The agreement is irrevocable in addition to the agreement of both parties, or for reasons prescribed by law. Consent must be performed in good faith'. Therefore, all the contents of the agreement that has the brand owner with the owner of the capital made on the joint agreement, must be followed such as the validity of the law that they are obliged to follow as long as the agreement is still valid within the period specified in the agreement and can only expire when the term of the agreement expires, expires due to the law, or expires. However, the explanation of the rights and obligations of the parties involved in the agreement still there is a deficiency, especially in the rights and obligations of capital owners, between the amount of the contents of rights not balanced by the amount of the contents of obligations, should be the sum of each of the rights and obligations balanced or not far different between the amount of rights and obligations. Then, regarding the explanation of the profit sharing is not mentioned in the article rights and obligations, such as explanations about the time of the profit sharing and the division through direct payment or transfer, in the article is not explained in detail. Some of the things that made the weak legal force on the Akad Syirkah Mudharabah Ayam Geprek Sa'i.

The agreement must be carried out based on good faith; it aims to protect someone from the deeds of the parties involved in the agreement so that it can avoid any difficulties or losses. It means the agreement must not against the laws, regulations and norms applicable in Indonesia.

However, In the implementation of Akad Syirkah Mudharabah in the culinary activities of the fast food restaurant Ayam Geprek Sa'i, there can be found rights and obligations that are not well realized so that it poses a conflict between the parties related. One of them is tort. The understanding of the default is one who, if he does not fulfil his or her obligations, meets his obligations but does not conform to what has been promised. ${ }^{15}$ It can also be interpreted as a deed of promise done by one party that does

\footnotetext{
${ }^{15}$ Subekti, (2007), Kitab Undang-Undang Hukum Perdata, Jakarta: Rajawali Pers, p. 146.
} 
not execute the content of the agreement or execute but it is delayed or do a deed that can not be done in accordance with what has been promised.

As for the default that happens is the delay of fulfilment of payments made by the management to the capital owners, ${ }^{16}$ where in Article 3 in the Akad Syirkah Mudharabah Ayam Geprek Sa'i has been listed in the share of profit result is with a system for the result of $30 \%$ obtained for the owner of the brand/Management manager and $70 \%$ obtained for the capital owner taken from profit profits. In the calculation of this division is done by the brand owner as a management that will share $70 \%$ of the profit profits to the party capital at a specified time according to the mutual agreement, such as profit sharing is done every 1 month, on every 1 st. However, management does not do so in accordance with what has been agreed, meaning management is late in the sharing of such profits. This can be detrimental to the capital owner, because if the profit is being needed by the capital owner, it will be very likely to impact the losses. ${ }^{17}$

It is then in accordance with Article 1243 of the Civil Code concerning the tort, stated that reimbursement, loss and interest due to the absence of a particular alliance, shall begin to be obliged, if the debt, after it is declared negligent to fulfil its case, still neglect it, or if something to be given or made, can only be given or done or can only be given or created in the period that has been enclosed. This means that for solutions to resolve such default management parties must fulfil their obligations within the specified timeframe and evaluate themselves not to do the same over and over again. In doing so, the capital owners are facum in running their business.

The share of profit, moreover, can be done by the capital owners but it can be a conflict in the business relationship because there is an inequality in the calculation of profit. ${ }^{18}$ For example, if in January the business margin of restaurant Ayam Geprek Sa'i reached a value of Rp 10 million,-. Calculation of profit sharing according to the owner of the brand resulted in a value of Rp 3.5 million,-for the profit earned by the brand owner and Rp 6.5 million,-for the profit earned for the capital owner. Then, the calculations are also done by the capital owners, which resulted in a value of Rp 3 million,-for the profit obtained by the brand owner and $\mathrm{Rp} 7$ million,-for profit earned for the capital owner. The difference in the outcome of this calculation can then be a conflict between the two parties.

According to the provisions of Article 5 Paragraph (1) of the Akad Syirkah Mudharabah Ayam Geprek Sa' $i$, that is 'the calculation of profit loss is carried out on a monthly basis by the second party (Mudharib). In the implementation there is still problem that does not comply with what has been held in the agreement. Therefore, it is

\footnotetext{
${ }^{16}$ Result of interview with Mr. Hafidz, Capital Owner of Ayam Geprek Sa'i, in Yogyakarta, on March 11th 2020, at $07.00 \mathrm{pm}$.

${ }^{17}$ Result of interview with Mr. Hafidz, Capital Owner of Ayam Geprek Sa'i, in Yogyakarta, on March 11th 2020, at $07.00 \mathrm{pm}$.

${ }^{18}$ Result of interview with Mr. Hafidz, Capital Owner of Ayam Geprek Sa'i, in Yogyakarta, on March 11 th 2020 , at $07.00 \mathrm{pm}$.
} 
best to do a business should be in accordance with what has been agreed, where the management who manages the calculation of profit loss from the business trip and the capital owners only receive the results. Although, the capital owner has the right to control or review its business activities, both sides must keep up with what has been agreed, in order to avoid conflict in business relationships.

The management also at any time send the bill to the owner of the capital, which from the capital owner himself feel less understanding where the bill came from. These bills can be a burden on capital owners and are considered detrimental due to the uncertainty of management in communicating where the bills come. ${ }^{19}$

According to the provisions of Article 5 Paragraph (2) of the Akad Syirkah Mudharabah Ayam Geprek Sa'I, that is 'the results of the calculation of losses and financial statements are informed in written form to the first party or by e-mail'. This is stated in the agreement that it should be agreed by both parties agreed, where it has been in accordance with the implementation. However, the information provided by the management to the capital owner is less obvious. It is therefore necessary for clear communication and transparency between the parties in the business activities of Ayam Geprek $S^{\prime} i$. The capital owner has the right to submit proposals and advice to the management; this is stated in Article 6 letter (e) Akad Syirkah Mudharabah Ayam Geprek Sa'i, but still in a joint agreement.

Then related to communication, management also at any time do the employee rolling suddenly, ${ }^{20}$ although the management has the right to manage and determine the policies in the business activities listed in Article 6 letter (e) Akad Syirkah Mudharabah Ayam Geprek Sa'i. However, it is also felt to harm the owner of the capital, considering that the business is done by two parties, should the management communicate it to the capital owners in advance in a planned.

This is contrary to Article 2 Letter D Regulation of the Regional Government of Yogyakarta Number 9 Year 2017 which mentions the principle of transparency of the empowerment and protection of creative industries, cooperatives, and small businesses conducted while maintaining and promoting the disclosure of true, honest and nondiscriminative information about the price, market, source, and availability of raw materials, as well, Cooperatives and small businesses.

Therefore, transparency in the business relationship is very important, because without the transparency between the two parties, it can increase the risk of conflicts that occur due to suspicion by one party on the other. It is also very important to create a fair and peaceful business venture. Therefore, the brand owner as a management restaurant manager Ayam Geprek Sa'i should follow the recommendation of the

\footnotetext{
${ }^{19}$ Result of interview with Mr. Hafidz, Capital Owner of Ayam Geprek Sa'i, in Yogyakarta, on March 11 th 2020 , at $07.00 \mathrm{pm}$.

${ }^{20}$ Result of interview with Mr. Hafidz, Capital Owner of Ayam Geprek Sa'i, in Yogyakarta, on March 11th 2020 , at $07.00 \mathrm{pm}$.
} 
prevailing laws and regulations, especially on the matter of transparency, so that no misunderstanding occurred between the parties. Unfortunately, only one of the components of the fair and equitable treatment standard is mentioned---transparency. ${ }^{21}$

In case of reimbursement that if this happens, only the property loss is borne by the capital owner entirely, while the management only bears the loss of time and effort. It is listed in Article 4 of the Akad Syirkah Mudharabah Ayam Geprek Sa'i, so that the capital owner can not claim compensation in the form of material to the brand owner as a management party.

Then in solving a problem, the agreement is explained only through deliberation. However, if such deliberation is unable to resolve the conflict, it can be resolved through the legal pathway. It is listed in Article 9 Akad Syirkah Mudharabah Ayam Geprek Sa'i.

The law has also been governed by the legal protections of the parties due to the negligence made by the other party. The disadvantage is the loss of material and loss of Imateriil. Due to the legal consequences of an omission, the injured party may claim damages to the other party which negligent the legal basis of Article 1267 of the Civil Law stating that 'the party against whom the alliance is not fulfilled, may vote; The other party to fulfill its consent, if it is still possible, or requires cancellation of consent, with reimbursement of costs, losses and interest'.

Furthermore, in the event of termination of the agreement, Article 8 of the Akad Syirkah Mudharabah Ayam Geprek Sa'i has mentioned that the agreement of the Akad Syirkah Mudharabah Ayam Geprek Sa'i is valid only within 3 years only, then the agreement can be reviewed again to be renewed and or re-directed by both parties. However, the agreement may also terminate before the term of the agreement ends in accordance with the agreement of both parties.If one of the parties agrees to pass on, the agreement will be continued by the heirs of each party agreeing.

The essences of this research that is importance for business people who will conduct business activities to understand all of the contents of the agreement, ranging from the system of its business activities, rights and obligations, and the legal force on its business activities, and others related to its business. It aims to avoid any misunderstanding that poses a conflict in the business relationship.

\section{Conclusion}

Ayam Geprek Sa'i business is a partnership business that uses Akad Syirkah Mudharabah, which uses a profit-share system. Akad Syirkah Mudharabah Ayam Geprek Sa'i itself is an agreement that uses the default clause, in which the rights and

${ }^{21}$ Monebhurrun, N, (2016), Novelty in International Investment Law: The Brazilian Agreement on Cooperation and Facilitation of Investments as a Different International Investment Agreement Model, Journal of International Dispute Settlement,0, 1-22, p. 15 idv028. doi:10.1093/jnlids/idv028 
obligations of the parties listed in the agreement are determined unilaterally by the brand owner as the management party, and the business person interested in becoming the capital owner on the Ayam Geprek Sa'i business brand has no right to change or the entire contents of the agreement. In the Akad Syirkah Mudharabah Ayam Geprek Sa'i there are also weaknesses that cause problems in its implementation, including vagueness about the arrangement of rights and obligations for the parties itself. Regarding the arrangement stipulated in the rights and obligations for the owner of the parties is stipulated in Article 6 of the Akad Syirkah Mudharabah Ayam Geprek Sa'i. However, in its implementation it is still not in accordance with what has been agreed in the agreement. Therefore, the parties should understand the content of an agreement they have agreed upon before conducting the business and evaluate each other about the rights and obligations of each party.

\section{References}

\section{Books}

Ahmad Azhar Basyir, (2000), Asas-Asas Hukum Muamalat, Yogyakarta: UII Press.

Muhammad Syafi'i Antonio, (2001), Bank Syariah: Dari Teori ke Praktik, Jakarta: Gema Insani

Hasanuddin Rahman, (2003), Aspek-Aspek Hukum Pemberian Kredit Perbankan di Indonesia, Bandung: Citra Aditya Bakti

Subekti, (1996), Hukum Perjanjian, Jakarta: PT. Intermasa

Subekti, (2007), Kitab Undang-Undang Hukum Perdata, Jakarta: Rajawali Pers

\section{Journals}

Chefi Abdul Latif, (2020), Pembiayaan Mudharabah Dan Pembiayaan Musyarakah Di Perbankan Syariah, Jurnal Ilmu Akuntansi dan Bisnis Syariah, Vol. II, No. 01.

Hananto Prasetyo, (2017), Perjanjian Sportentertainment Berbasis Nilai Keadilan (Studi Kasus pada Petinju Profesional di Indonesia), Jurnal Pembaharuan Hukum, Vol. IV No. 1 Edisi Januari-April.

Inda Rahadiyan dan M. Alif Akbar Pranagara, (2017), Bentuk Hubungan Hukum Para Pihak dan Tanggung Jawab Agen dalam Penyelenggaraan Branchless Banking di Indonesia, Jurnal Hukum IUS QUIA IUSTUM No. 2 Vol. 24. Edisi April.

Mahmudatus Sa'diyah, Meuthiya Athifa Arifin, (2013), Mudharabah dalam Fiqih dan Perbankan Syari'ah, EQUILIBRIUM No. 2 Vol. 1. Edisi Desember.

Monebhurrun, N. (2016), Novelty in International Investment Law: The Brazilian Agreement on Cooperation and Facilitation of Investments as a Different 
International Investment Agreement Model, Journal of International Dispute Settlement, 0, 1-22, idv028. doi:10.1093/jnlids/idv028

\section{Regulations}

Civil Code (KUH Perdata)

Compilation of Sharia Economic Law (KHES)

Law Number 8 Year 1999 on Consumer Protection

Regulation of Yogyakarta Special Region Number 9 Year 2017 about Empowerment and Protection of Creative Industries, Cooperatives, and Small Business

\section{Internet}

Ayamgeprek-sai.com, Ayam Geprek Sa'i adalah manajemen kemitraan berbasis syariah, 2017, <http://ayamgeprek-sai.com/tentang_kami.html > [accessed on 30 November 2019 14:00 WIB]. 